\title{
Employee Performance Apparaisal Using Decision Support System by AHP and TOPSIS Methods
}

\author{
Achmad Baroqah Pohan ${ }^{1}$, Sofian Wira Hadi ${ }^{2}$, Syaifur Rahmatullah ${ }^{3}$, Robi Aziz Zuama ${ }^{4}$, Achmad \\ Rifai $^{5}$, Deni Gunawan ${ }^{6}$ \\ ${ }^{1,4,6}$ Faculty of Engineering and Informatics, Universitas Bina Sarana Informatika, J1. Kramat Raya No.98 , \\ Jakarta, Indonesia \\ ${ }^{1}$ Email : Achmad.abq@bsi.ac.id \\ 4 Email : Robi.rbz@bsi.ac.id \\ 6 Email : Deni.dee@bsi.ac.id
}
${ }^{2}$ Computer Science Department, STMIK Nusa Mandiri, Jakarta, Indonesia, Jl. Jatiwaringin Raya No.2 , Jakarta, Indonesia
${ }^{2}$ Email : $14002361 @$ nusamandiri.ac.id
${ }^{3,5}$ Informatic Engineering Department, STMIK Nusa Mandiri , J1. Jatiwaringin Raya No.2 , Jakarta, Indonesia
${ }^{3}$ Email : syaifur.syl@nusamandiri.ac.id
${ }^{5}$ Email : Achmad.acf@ nusamandiri.ac.id

\begin{tabular}{ccc}
\hline Diterima & Direvisi & Disetujui \\
$14-12-2020$ & $21-12-2020$ & $24-01-2021$ \\
\hline
\end{tabular}

\begin{abstract}
Abstrak - penilaian kinerja PT. Injep Inti Cemerlang selama ini belum optimal, khususnya dalam penilaian kinerja karyawan. Penilaian kinerja selama ini hanya ditentukan dari hasil, belum ada kriteria penilaian yang jelas. Untuk itu diperlukan suatu sistem pendukung keputusan untuk membantu mencari alternatif terbaik dalam pemilihan karyawan. Penelitian ini mengembangkan sistem pendukung keputusan untuk penilaian kinerja karyawan berdasarkan Attitude, Responsibility, Attendance, Discipline dan Collaboration. Tujuannya untuk merancang sistem pendukung keputusan penilaian kinerja karyawan dengan menggunakan metode pengumpulan data melalui observasi, wawancara dan pemberian kuesioner kepada karyawan. Pengumpulan data dilakukan dengan proses menganalisis data dan mencari nilai pembobotan menggunakan metode AHP dan untuk pemeringkatan menggunakan metode TOPSIS, dimana masing-masing kriteria merupakan faktor penilaian dan alternatif dalam hal ini karyawan dibandingkan dengan kriteria yang telah dibobotkan melalui Proses penghitungan metode AHP dan TOPSIS dimulai dari pemberian pembobotan kriteria dengan menghitung dengan Ms. Excel dan menghitung dengan software Expert Choice. Hasil tersebut diperoleh dari pembobotan pemeringkatan selanjutnya dengan metode TOPSIS. sehingga memberikan nilai keluaran yang menghasilkan suatu sistem penilaian karyawan. Sistem pendukung keputusan ini membantu penilaian kinerja karyawan pada PT. Injep Inti Cemerlang dalam menentukan karyawan yang memiliki kinerja terbaik.
\end{abstract}

Keywords: Sistem Pengambilan Keputusan , AHP, TOPSIS, Kinerja Karyawan

\begin{abstract}
During this time the performance appraisal of PT. Injep Inti Cemerlang has not been implemented optimally, especially in employee performance appraisal. Performance appraisal so far is only determined from the results, there are no clear appraisal criteria. Based on this reason, a decision support system is needed to help find the best alternative for the employees selection. In this research a decision support system for employee performance appraisal will be developed based on Attitude, Responsibility, Attendance, Discipline and Collaboration. This research aims to design a decision support system for employee performance appraisal using data collection methods by observation, interviews and giving questionnaires to employees of PT. Injep Inti Cemerlang. The data collected is carried out the process of analyzing data and looking for weighting values using the AHP method and for ranking using the TOPSIS method, where each criterion is appraisal factors and alternatives in this case employees are compared the criteria that have been weighted through the process of calculating the AHP and TOPSIS method starting from giving the weighting of criteria by calculating with Ms. Excel and calculating with Expert Choice software. The results have been obtained from weighting the next ranking by the TOPSIS method. thus providing a value output that results in a system that employees appraisal. This decision support system helps the employee performance apprasial at PT. Injep Inti Cemerlang in determining the employee who has the best performance.
\end{abstract}

Keywords: Decision Support System, Analytical Hierarchy Process (AHP), TOPSIS, Employee Performance 


\section{INTRODUCTION}

According to (Yunus, 2016) The running of a management in a company certainly cannot be separated from the evaluation process in order to organizational goals can be achieved effectively and efficiently. One function of important evaluation is the employee performance appraisal. These activities have become common, especially in the company. It is carried out to appraise the existing performance in order to immediately take an action if there are deviant thing from the performance appraisal. In addition, employee performance appraisals also encourage employees to increase the quantity and quality of their work for the company. Therefore, the company needs to do employee performance appraisal, considering that employees are fundamentals as a part of the company development..

According to (Frieyadie, 2018) the best employee is one of the main supports for the achievement of an institution. According to the Law of the Republic of Indonesia No13 2003, Workers are every person who are able to do work in producing goods and / or services for their own needs and society. PT. Injep Inti Cemerlang is a company engaged in the field of complementary facilities and infrastructure providers roads in Indonesia, PT. Injep Inti Cemerlang has competent employees in their fields and supported by skilled and experienced technical personnel to guarantee the quality of work that is in accordance with expectations. PT. Injep Inti Cemerlang implement standard operational procedures (SOP) with the support of adequate research data as well as the achievement of quality-control standards in each field and the management also has conducted an appraisal process. However, it has not been implemented optimally, especially in employee performance appraisal. All this time is only determined from the results of his work, there are no clear appraisal criteria. According to Rivai in (Amalia \& Utami, 2018), the performance appraisal refers to a formal and structured system that is used to measure, evaluate and influence the characteristics related to work, behavior, and results, including the absence level.

Decision support system is the right solution in the decision of employee performance appraisal process. The research that has been developing to date generally uses the SAW and TOPSIS methods most widely used in the decision making process (Mude, 2016). In a previous study with the title Employee Performance Appraisal Decision Support System this research used the SAW method (Simple Additive Weighting) at Muhammadiyah University, Purwokerto (Anto, Mustafidah, \& Suyadi, 2015). The research discusses five criteria for evaluating employee performance, such as, general appraisal, the attendance level, education level, personal development, supporting elements. Subsequent research with the title decision support system for employee performance appraisal using the TOPSIS method (Technique For Others Reference By Similarity To Ideal Solution) at PT. Rio Utama Samarinda (Yusnita, Salmon, \& Ramadhan, 2015) in this research discuss seven criteria for employee performance appraisal, including, Work Quality, Discipline, Competence, Collaboration, Behavior, Initiative, Appearance. The alternative chosen is close to the positive ideal solution and has a long distance from the negative ideal solution. Composites of the best work values displayed by each alternative for each attribute will form the ideal solution. The disadvantage of this method is there is no priority weights determination that prioritizes the chosen criteria. Another research with the title Decision Support System for Employee Performance Appraisal Using the Analytical Hierarchy Process method (AHP) in Serang District Hospital, this research is to build an employee performance appraisal using decision support system AHP method (Saefudin \& Wahyuningsih, 2014). According to (Khairunnisa, Farmadi, \& Candra, 2015) AHP-TOPSIS method has their respective roles to speed up the process and produce optimal decision values. AHP is used for weighting the criteria is useful to enhance the validity of the weight value calculation criteria and TOPSIS has role in determining alternative ranking.

From the background knowledge that has been analyzed it is expected to get more effective and efficient results. Therefore the researchers motivated to make research at PT. Injep Inti Cemerlang by creating a decision support system of employee performance using the Analytical Hierarchy Process (AHP) method and Technique For Order Preference by Similarity to Ideal Solution (TOPSIS)

\section{RESEARCH METHODOLOGY}

At the observation stage, researchers carry out direct observations of the performance appraisal process to find information and collect data at PT. Injep Inti Cemerlang Jl. 1 Siliwangi No 12 RT / RW 05/03 Desa, Cibeuteung Udik, Ciseeng, Bogor, West Java 16120. In this interview stage the researchers interviewed Ms. Lia Apriyanti, S.Kom, the administrative staff of PT. Injep Inti Cemerlang by preparing a number of questions regarding problems that occur in the company. Researcher questionnaire was given to the staff of PT. Injep Inti Cemerlang to complete research data in determining employee performance appraisal rankings.

\subsection{Decision Support System}

Decision support system is an interactive computer-based information system, by processing data with various models to solve unstructured problems so that it can provide information that can be used by decision makers in making a decision 
(Chamid \& Murti, 2017). It can be concluded that the decision support system is a specific information system intended at assist management in making decisions relating to semi-structured issues.

Based on DSS support, the researchers use What-ifAnalysis and Goal Seeking Analysis in the employee performance research phase of PT. Injep Inti Cemerlang.

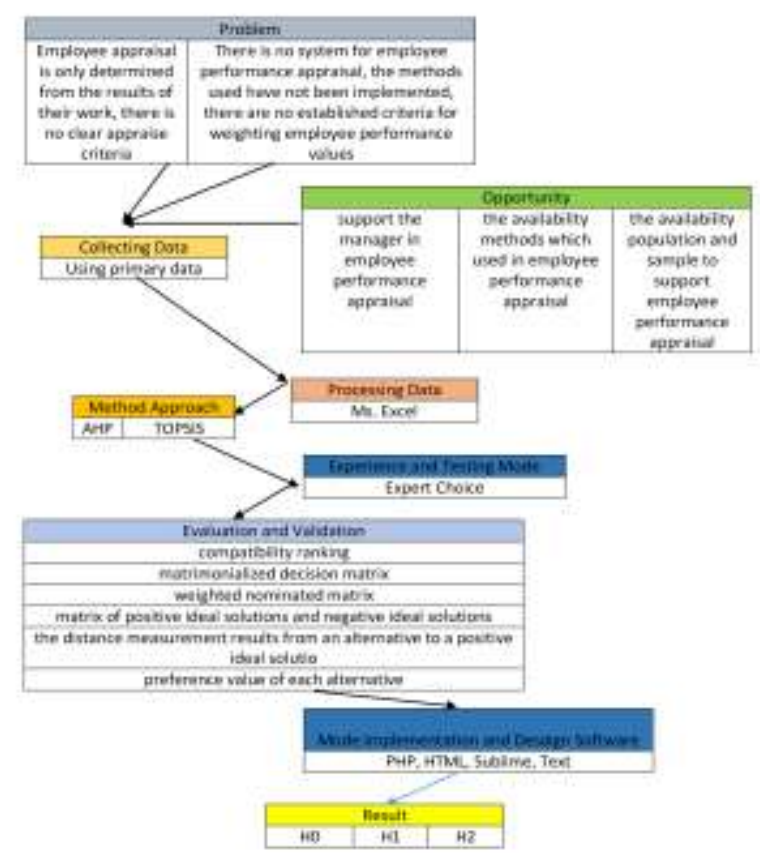

3.2. Analytical Framework

Figure 1. Analytical Framework

\section{FINDINGS AND DISCUSSION}

\subsection{Analysis Using AHP Method}

Analyzing the final results of the selection of the best employee performance must be in accordance with predetermined criteria ranging from attitude, responsibility, attendance, discipline and collaboration. It is necessary for the weighting criteria using AHP method and finds the consistency values to be used in TOPSIS method. Data and values is taken from the overall results of the questionnaire to determine the final results of the best employee performance appraisal. The following criteria for respondents were determined:

a. The office employees are respondents.

b. The requirements become a respondent are the highest positions at PT Injep Inti Cemerlang and know the performance of the field employees.

c. 1 respondent evaluated 16 the field employees. d. There are 4 respondents consisting of the Head of the department

e. Respondent calculation using Geeometric Mean Theory or called answer smoothing, to get a certain value from that value, then the results must be multiplied by each other, and the product of multiplication is raised by $1 / \mathrm{n}$ where $\mathrm{n}$ is the number of respondents. Systematically the equation is as follows:

$\sqrt[n]{a 1 x a 2 x a 3 x a 4 \ldots \ldots x a n}$

f. The questionnaire given there are two methods, namely the Questionnaire to determine suitability perception level (TOPSIS) and the importance level of expectations on each appraisal criteria for each alternative that has been determined (AHP)

The analysis to determine the priority criteria using the AHP method as follows:

Table 1. Pairwise Comparison Matrices

\begin{tabular}{|l|l|l|l|l|l|}
\hline GOAL & C1 & C2 & C3 & C4 & C5 \\
\hline C1 & 1,00 & 5,00 & 3,00 & 5,00 & 2,00 \\
\hline C2 & 0,20 & 1,00 & 0,25 & 4,00 & 0,50 \\
\hline C3 & 0,33 & 4,00 & 1,00 & 5,00 & 1,00 \\
\hline C4 & 0,20 & 0,25 & 0,20 & 1,00 & 0,50 \\
\hline C5 & 0,50 & 2,00 & 1,00 & 2,00 & 1,00 \\
\hline
\end{tabular}

Table 2. Criteria Value Matrix

\begin{tabular}{|l|l|l|l|l|l|l|l|}
\hline GOAL & C1 & C2 & C3 & C4 & C5 & Total & $\begin{array}{l}\text { Prority } \\
\text { Vector }\end{array}$ \\
\hline C1 & 0,45 & 0,41 & 0,55 & 0,29 & 0,40 & 2,10 & 0,42 \\
\hline C2 & 0,09 & 0,08 & 0,05 & 0,24 & 0,10 & 0,55 & 0,11 \\
\hline C3 & 0,15 & 0,33 & 0,18 & 0,29 & 0,20 & 1,15 & 0,23 \\
\hline C4 & 0,09 & 0,02 & 0,04 & 0,06 & 0,10 & 0,31 & 0,06 \\
\hline C5 & 0,22 & 0,16 & 0,18 & 0,12 & 0,20 & 0,89 & 0,18 \\
\hline Total & 1,00 & 1,00 & 1,00 & 1,00 & 1,00 & 5,00 & \\
\hline
\end{tabular}

Table 1 explains that the recapitulation of combined pairwise comparison matrix results on 4 (four) respondents. Table 2 explains that the elements of each column are divided by the related number of columns and a normalized relative weight will be obtained 
Table 3. Consistency Ratio Calculation

\begin{tabular}{|l|l|l|l|l|}
\hline Goal & $\begin{array}{l}\text { Number } \\
\text { of Rows }\end{array}$ & Priority & Quotient & Quotient/Priority \\
\hline C1 & 16 & 0,42 & 2,32 & 5,52 \\
\hline C2 & 5,95 & 0,11 & 0,58 & 5,29 \\
\hline C3 & 11,33 & 0,23 & 1,29 & 5,61 \\
\hline C4 & 2,15 & 0,06 & 0,31 & 5,13 \\
\hline C5 & 6,5 & 0,18 & 0,96 & 5,33 \\
\hline Total & & & & 5,38 \\
\hline
\end{tabular}

Total $=5,38$

$\mathrm{N}=5(\mathrm{IR}=1.19)$

$\operatorname{Max}=5,38$

$\mathrm{CI}=(5,38-5) / 5-1=0,09$

$\mathrm{CR}=0,09 / 1.19=0,08$ because $\mathrm{CR}<0,1$, the consistency ratio calculation is acceptable.

According to the calculation results the table above shows that Attitude criteria is the most important criterion in employee performance appraisal becomes the first priority with a weighting value of $42 \%$, then attendance becomes the second priority with a weighting value of $23 \%$, then collaboration becomes the third priority with a weighting value of $18 \%$, then responsibility becomes the fourth priority with a weighting value of $11 \%$ and finally discipline becomes the fifth priority with a weighting value of $6 \%$.

\subsection{Testing AHP Method with Expert Choice}

Determining maximum results, AHP method testing with Expert Choice is needed. The results obtained in the Expert Choice are as follows:

\begin{tabular}{|c|rrrrr|}
\hline Attitude & Responsibility & Attendance & Discipline & Collaboration \\
\hline & & 5,0 & 3,0 & 5,0 & 2,0 \\
& & 4,0 & 4,0 & 2,0 \\
\hline & & & 5,0 & 1,0 \\
\hline & & & & 2,0 \\
\hline \hline Incon:0,08 & & & & & \\
\hline \hline
\end{tabular}

Figure 2. Pairwise Comparison Matrix

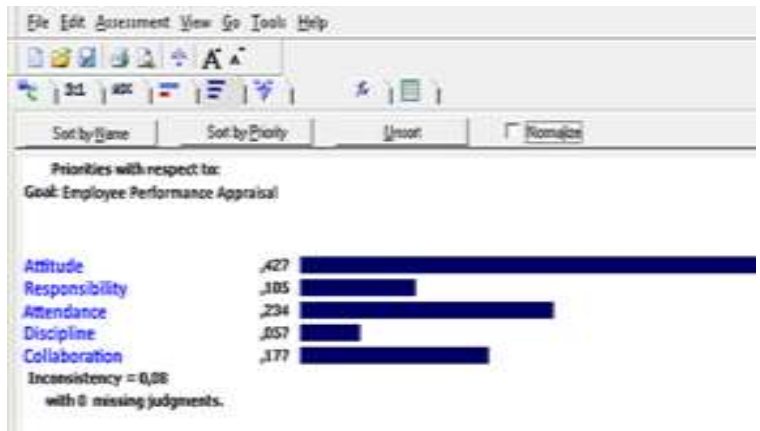

Figure 3. Consistency Ratio
Figure 2 explains that the recapitulation of the combined pairwise comparison matrix results from 4 (four) respondents were inputted into the Expert Choice. Overall inconsistensy 0,08 because $\mathrm{CR}<0,1$, then the consistency ratio calculation is acceptable.

According to the calculation results in the picture above (Expert Choice) shows that the Attitude criteria is the most important criterion in employee performance appraisal become the first priority with a weighting value of 0.427 , then attendance becomes the second priority with a weighting value of $0.234 \%$, then collaboration becomes a priority the third with a weight value of 0.177 , then responsibility becomes the fourth priority with a weight value of 0.105 and finally discipline becomes the fifth priority with a weight value of 0.57 .

Therefore manual calculation is the same as calculation in Expert Choice by having a consistency ratio value of 0.08 because less than 0.1 such calculation is acceptable and can be implemented.

\subsection{Analysis Using TOPSIS Method.}

The TOPSIS method plays a role in determining alternative ranking. Getting a matches ranking from alternative employee performance appraisals, it must determine the value of compatibility between alternatives and criteria with intervals of 1 to 5 , with the provisions of $1=$ Poor, $2=$ Fairly Poor, $3=$ Fairly Good, 4 = Good, 5 = Excellent.

Table 4. Reference Value of each Alternative for ranking each Alternative

\begin{tabular}{|l|l|}
\hline V1 & $\mathbf{0 , 5 3 6 5 6}$ \\
\hline V2 & 0,5554 \\
\hline V3 & 0,58642 \\
\hline V4 & 0,4465 \\
\hline V5 & 0,39338 \\
\hline V6 & 0,34907 \\
\hline V7 & 0,5611 \\
\hline V8 & 0,5611 \\
\hline V9 & 0,58642 \\
\hline V10 & 0,41358 \\
\hline V11 & 0,44172 \\
\hline V12 & 0,48821 \\
\hline V13 & 0,16032 \\
\hline V14 & 0,4726 \\
\hline V15 & 0,26612 \\
\hline V16 & 0,58762 \\
\hline
\end{tabular}

DSS based on the determined value criteria by Dery has a value of 4.73 (Attitude) Excellent, 3.46 (Responsibility) Fairly Good, 3.46 (Attendance) 
Fairly Good, 4.47 (Discipline) Fairly Good, 4.00 (Collaboration) Good. According to TOPSIS calculation, it can be obtained the best performance appraisal recommendations for employees of PT Injep Inti Cemerlang who got the criteria is V16, namely Derry, 24 years with a preference value of 0.58762 . This can be used as material for the employees performance appraisal at PT. Injep Inti Cemerlang.

\section{IMPLEMENTATION}

The system implementation is based on predetermined design specifications. The implementing result of decision support system for employee performance appraisal are as follows:

\subsection{Criteria Page}

The Criteria page functions is add or delete criteria and appraise weight to values that have been searched by using software expert choice.

\subsection{Alternative Page}

The Alternative page is used to add or delete employee candidates who want to be appraised..

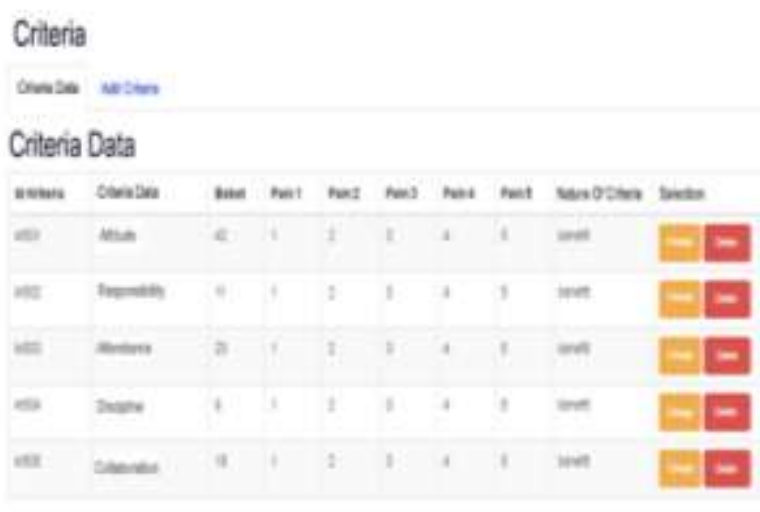

Figure 4. Criteria Page

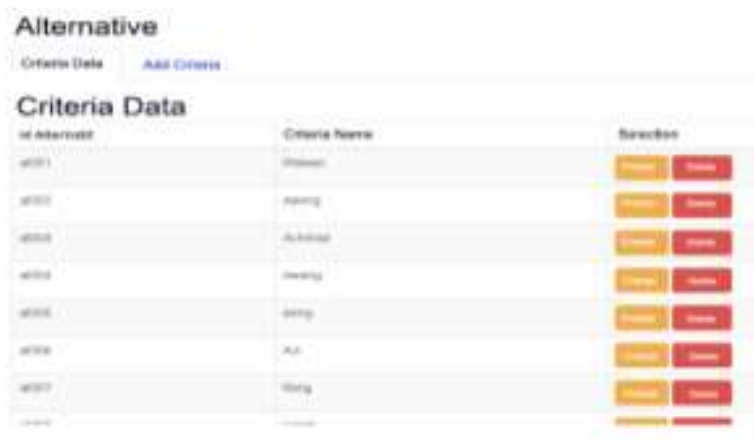

Figure 5. Alternative Page

\subsection{Matrix Value}

The matrix value page is a page for appraising alternatives with predetermined criteria.

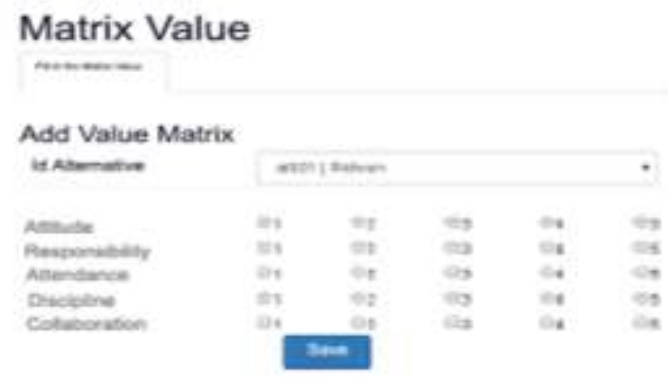

Figure 6. Matrix Value

\subsection{TOPSIS Results Page}

The TOPSIS results page is a page to notice the calculation results, the nominal matrix value, the nominal weighted value, the positive / negative ideal matrix, the distance of positive / negative ideal solution and the preference value.

\section{Topsis Result}

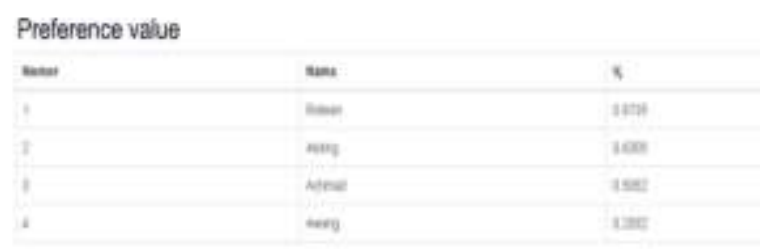

Figure 7. TOPSIS Results Page

\section{CONCLUSION}

After going through the stages of appraisal and analyzing data, the researcher can conclude about the employee performance appraisal with 16 field employee candidates who are in PT Injep Inti Cemerlang, the conclusions that researchers have obtained are as follows:

1) Criteria given by researchers are mighty influential on employee performance appraisal, it can be noticed from the calculation of data obtained, namely Attitude criteria is the vital criterion in employee performance appraisal become the fist priority with a weighting value of $42 \%$, then attendance becomes the second priority with a weighting value of $23 \%$, then collaboration becomes the third priority with a weighting value of $18 \%$, then responsibility becomes the fourth priority with a weighting value of $11 \%$ and the last is discipline being the fifth priority with a weighting value of $6 \%$ 
2) According to weighting criteria results, it can be used to determine ranking by using the TOPSIS method. It is quite helpful for employee performance appraisal and the results obtained from the AHP and TOPSIS methods, namely Derry, 24 Years with a preference value of 0.58762 .

3) AHP and TOPSIS methods are suitable methods for making decisions, not only for employee performance appraisal but also for other choices. The accepted hypothesis is H0

\section{REFERENCE}

Anto, A. G., Mustafidah, H., \& Suyadi, A. (2015). Sistem Pendukung Keputusan Penilaian Kinerja Karyawan Menggunakan Metode SAW ( Simple Additive Weighting ) di Universitas Muhammadiyah Purwokerto ( Decision Support System of Human Resources Performance Appraisal Using SAW ( Simple Additive Weighting ) M, III(November), 193-200.

Busro, M. (2018). TEORI-TEORI MANAJEMEN SUMBER DAYA MANUSIA (pertama). Jakarta.

Candra, H. K., Farmadi, A., \& Khairunnisa. (2015). PENERAPAN METODE AHP TOPSIS PADA SISTEM PENDUKUNG KEPUTUSAN PENENTUAN TAMAN, 02(01), 1-10.

Chamid, A. A., \& Murti, A. C. (2017). Fakultas Teknik Universitas Muria Kudus 115, 115-119.

Desyanti. (2016). MENGGUNAKAN METODE ANALITICY HIERARCY PROCESS ( AHP ), 1(1).

Djunaedi, A., Subiyakto, A., \& Fetrina, E. (2017). SISTEM PENDUKUNG KEPUTUSAN PENILAIAN KINERJA PEGAWAI ( Studi Kasus: PT . PLN ( Persero Distribusi Jakarta Raya Area Pondok Gede )), 10(1), 37-44]
Frieyadie. (2018). Metode ahp sebagai penunjang keputusan untuk penilaian kinerja kerja karyawan spbu, 15(1), 63-68.

Mardiana, T. (2018). SISTEM PENDUKUNG KEPUTUSAN PENERIMAAN ASISTEN LABORATORIUM KOMPUTER MENGGUNAKAN METODE AHPTOPSIS, 3(2), Bandung 159-166.

Mude, M. A. (2016). PADA KASUS UMKM, 8(Agustus), 76-81.

Noermijati. (2013). Kajian Tentang AKTUALISASI TEORI HERZBERG, KEPUASAN KERJA DAN KINERJA SPRITUAL MANAJER OPERASIONAL (Pertama). Malang.

Nofriansyah, D., \& Defit, S. (2017). MULTI CRITERIA DECISION MAKING (MCDM) pada Sistem Pendukung Keputusan (pertama). yogyakarta.

Nurdiyanto, H., \& Meilia, H. (2016). SISTEM PENDUKUNG KEPUTUSAN PENENTUAN PRIORITAS PENGEMBANGAN INDUSTRI KECIL DAN MENENGAH DI LAMPUNG TENGAH MENGGUNAKAN ANALITICAL HIERARCHY PROCESS ( AHP ), Yogyakarta, 6-7.

Undang-undang Republik Indonesia Nomor 13 Tahun (2003).

Rizky, U. D. (2018). PEMBERIAN REWARD BERDASARKAN PENILAIAN KINERJA KARYAWAN DENGAN METODE AHP PADA PT.ANUGERAH PROTECINDO (2), 181-188.

Saefudin, \& Wahyuningsih, S. (2014). Sistem Pendukung Keputusan Untuk Penilaian Kinerja Pegawai Menggunakan Metode Analytical Hierarchy Process ( Ahp ) Pada RSUD Serang, (1), 33-37.

Sari, F. (2018). METODE DALAM PENGAMBILAN KEPUTUSAN. Yogyakarta.

Taufik, Pratomo, P. A., Ipnuwati, S., \& Wulandari. (2018) Implementasi Multi Attribute Decision Making Metode AHP dan TOPSIS untuk Menunjang Keputusan dalam Hal Penerimaan Pekerja ( Studi Kasus: PT . Bank Rakyat Indonesia ( Persero ), 418-431.

Yusnita, A., Salmon, \& Helmi, R. (2015). SISTEM PENDUKUNG KEPUTUSAN PENILAIAN KINERJA KARYAWAN MENGGUNAKAN METODE TOPSIS ( TECHNIQUE FOR OTHERS REFERENCE BY SIMILARITY TO IDEAL SOLUTION ) PADA PT . RIO UTAMA SAMARINDA, 1(Senatkom), 84-89.

Yunus, E. (2016). Manajemen Strategis. (A. A. Charitsman, Ed.). Yogyakarta. 